OPEN ACCESS

Edited by:

Angelica Lindén Hirschberg,

Karolinska Institute (KI), Sweden

Reviewed by:

Giancarlo Condello,

University of Taipei, Taiwan

Andrew McKune,

University of Canberra, Australia

*Correspondence:

Javier Gil-Ares

javier.gil@upm.es

Specialty section:

This article was submitted to

Exercise Physiology,

a section of the journal

Frontiers in Physiology

Received: 10 December 2020

Accepted: 24 May 2021

Published: 28 June 2021

Citation:

Sánchez-Polán M, Franco E,

Silva-José C, Gil-Ares J,

Pérez-Tejero J, Barakat $R$ and Refoyo I

(2021) Exercise During Pregnancy and

Prenatal Depression: A Systematic

Review and Meta-Analysis.

Front. Physiol. 12:640024.

doi: 10.3389/fphys.2021.640024

\section{Exercise During Pregnancy and Prenatal Depression: A Systematic Review and Meta-Analysis}

\author{
Miguel Sánchez-Polán ${ }^{1}$, Evelia Franco ${ }^{2}$, Cristina Silva-José ${ }^{1}$, Javier Gil-Ares ${ }^{1,3 *}$, \\ Javier Pérez-Tejero ${ }^{1,4}$, Rubén Barakat ${ }^{1,3}$ and Ignacio Refoyo ${ }^{5}$ \\ ${ }^{1}$ AFIPE Research Group, Universidad Politécnica de Madrid, Madrid, Spain, ${ }^{2}$ Department of Education, Research Methods \\ and Evaluation, Comillas Pontifical University, Madrid, Spain, ${ }^{3}$ Department of Physical Activity, Sports and Leisure Social \\ Sciences, Universidad Politécnica de Madrid, Madrid, Spain, ${ }^{4}$ Department of Health and Human Performance, Universidad \\ Politécnica de Madrid, Madrid, Spain, ${ }^{5}$ Department of Sports, Universidad Politécnica de Madrid, Madrid, Spain
}

Background: Prenatal depression is associated with an increased risk of physical, physiological, cardiovascular, and psychological diseases for mothers and future newborns. Prenatal depression and depressive symptoms could have negative effects on the cognitive, emotional, social, and behavioral development of children.

Objective: This study aimed to examine the influence of exercise during pregnancy on the prevalence of prenatal depression and depressive symptoms in the scientific literature.

Data Sources: A search was carried out examining different online databases up to November 2020.

Methods of Study Selection: A systematic review with random effects meta-analysis was performed. Only randomized controlled trials published in English or Spanish with pregnant populations and interventions with exercise programs carried out during pregnancy were included. The scores obtained by the tools that measured the emotional state and depressive symptoms as well as the number and percentage of depressed women of the study groups were analyzed.

Tabulation, Integration, and Results: We analyzed 15 studies and found a negative association between moderate exercise during pregnancy and prenatal depression $\left(\mathrm{ES}=-0.36,95 \% \mathrm{Cl}=-0.58,-13, l^{2}=80.2 \%\right.$, Pheterogeneity $\left.=0.001\right)$. In addition, the studies also showed that women who were inactive during pregnancy had a $16 \%$ higher probability of suffering prenatal depression $\left[R R=0.84(95 \% I C=0.74,0.96) I^{2}=61.9 \%\right.$, $\left.P_{\text {heterogeneity }}=0.010\right]$.

Conclusion: Supervised exercise during pregnancy may be useful for the prevention and reduction of prenatal depression and depressive symptoms.

Systematic Review Registration: Registered in PROSPERO (Registration No. CRD42020164819).

Keywords: exercise, pregnancy, prenatal depression, model, fetus 


\section{INTRODUCTION}

Depression (major depressive disorder) is an important, common, and serious medical illness that negatively affects how a person feels, thinks, and acts. Depression causes different symptoms, such as feelings of sadness, loss of interest/energy, difficulty thinking/concentrating, and/or thoughts of death or suicide. All symptoms can vary from mild to severe (Bienvenu et al., 2013).

During the last 20 years, the World Health Organization (2004) has monitored diseases associated with depressive symptoms and the dangerous growth rate of the prevalence of these diseases within developed countries. Pregnant women are not exempt from depressive symptoms, and pregnancy is a particularly vulnerable time for depression to occur compared with other periods of a woman's life (Campagne, 2004).

Indeed, the physical and psychological changes that occur in pregnant women are the largest promoters of this type of emotional lability (Lederman et al., 1997). Symptoms that alter emotional balance and lead to sickness (in some women) usually appear at the beginning of pregnancy; these symptoms, together with the fear of not being able to cope with the baby, hormonal changes, transformation of the female body, and the possible presence of a history of psychological disorders, lead to a complex condition and may be responsible for the well-known emotional lability during pregnancy (Barakat, 2006; Austin et al., 2008).

It seems that the relationships between gestational alterations of a psychological and emotional nature (depression, changes in self-esteem, anxiety, stress, insecurity, etc.) and physiological parameters (longer deliveries and more instrumental labors, altered birth weights, etc.) have been scientifically confirmed (Field et al., 2006; Rahman et al., 2007; Grote et al., 2010). This negative association extends beyond the gestational period, causing postnatal complications for both mothers and offspring (Hammond and Crozier, 2007; Deave et al., 2008; Hay et al., 2010; Field, 2011). Undoubtedly, the intrauterine environment is decisive for the life of future humans.

Recent studies have estimated the prevalence of depression during pregnancy to be between 10 and 30\% (Teixeira et al., 2009). It is closely associated with depression in the postpartum period, which has a prevalence of between 17 and 17.7\% (HahnHolbrook et al., 2018; Shorey et al., 2018).

Drug treatment during pregnancy is difficult and often questioned due to the possible side effects of antidepressants in the mother and fetus (Hammond and Crozier, 2007). Depression is a difficult complication to control because it is necessary to implement an intervention that avoids the possible negative effects on the fetus and the mother, such as altered brain development (O'Connor et al., 2002; Lee et al., 2007), an increased risk of preterm birth or intrauterine growth restriction (Field et al., 2006; Li et al., 2009; Field, 2011). Notwithstanding the aforementioned difficulty, it is clear that it is necessary to establish strategies that prevent the already proven, dangerous, and increasing association between prenatal depression and postpartum depression, which is a more well-known type of depression that involves a series of related complications, such as mother-child bonding difficulties (Wisner et al., 2009), infant feeding difficulties and infant overweight problems (Ertel et al., 2010), low birth weight and long hospital stays.

This situation constitutes an interesting incentive to investigate alternative treatments for depression (Hammond and Crozier, 2007). According to a review of studies about the effects of exercise on the non-pregnant population, previous studies report beneficial antidepressant effects (Barbour et al., 2007; Blumenthal et al., 2007; Martinsen, 2008). Furthermore, the results of previous investigations, involving psychological variables during an exercise program carried out in pregnant women are encouraging (Koniak-Griffin, 1994; Goodwin et al., 2000; Nordhagen and Sundgot-Borgen, 2002; Orr et al., 2006).

Over the last 30 years, exercise has been shown to have many benefits for pregnant women without a risk of adverse effects for maternal-fetal well-being provided that the activity is of a moderate intensity and is supervised by a professional. Although the scientific literature is not fully conclusive, there are many investigations indicating the positive effects of moderate exercise on the prevention of complications, including the adequate control of certain maternal, fetal, and newborn parameters (Barakat et al., 2015, 2016; Klein et al., 2018). However, due to fear, ignorance, or other factors, the prevalence of women who achieve the minimum weekly recommendation of exercise during pregnancy is 15-20\% (Mottola et al., 2018; Barakat et al., 2019).

The purpose of this systematic review and meta-analysis was to synthesize the literature and determine the effect of exercise during pregnancy on the prevalence of prenatal depression.

\section{METHODS}

This review was performed in accordance with the Preferred Reporting Items for Systematic Reviews and Meta-Analyses (PRISMA) guidelines (Moher et al., 2015) and was registered with PROSPERO, the International Prospective Register of Systematics Reviews (Registration No. CRD42020164819).

\section{Eligibility Criteria}

For this systematic review, the PICOS framework (population, intervention, comparison, outcome, study design) was used, and the nature of the interventions included in this research (Moher et al., 2015) was analyzed. Only articles written in English or Spanish and published between 2010 and 2020 were selected.

\section{Population}

The chosen population was pregnant women without any contraindication during pregnancy to undergo an exercise intervention during this period. Women suffering any absolute (e.g., heart failure, multiple pregnancy, or premature labor) or relative (e.g., essential arterial hypertension, cardiac arrhythmia, or anemia) contraindication were excluded from analyses.

\section{Intervention}

The following characteristics of the interventions were analyzed: (i) intensity: except for one study, all of the included studies had a light-to-moderate intensity of the load, which was prescribed using 55-65\% of maximum maternal heart rate and in some cases by means of the perception of effort (range 12-14 of the 
Borg Scale); (ii) duration of the program; (iii) type of exercise (e.g., aerobic, strength, balance, or pelvic floor training); (iv) weekly frequency of the sessions; (v) duration of the sessions; (vi) whether the exercise program was supervised by a professional; (vii) adherence of the sample to the exercise program; and (viii) in some studies analyzed, a complementary intervention with different outcomes was carried out, and so this was classified as "exercise + cointervention" as shown in Table $\mathbf{1}$.

\section{Comparison}

Women who engaged in exercise or physical activity were compared with those who did not. Additionally, the intervention characteristics were reviewed (shown in Table 1) to enrich our understanding of each study: no exercise intervention; weekly frequency, duration (both the program and sessions) or supervision of the program by a professional; mode of exercise; or if depression was a primary or secondary variable.

\section{Outcomes}

Target outcomes were the number of pregnant women with depression in both groups (to compare both the control and intervention groups) and the prenatal depression score of each depression questionnaire administered. The questionnaires dealing with prenatal depression among the selected articles were, in order of relevance, the Center for Epidemiologic Studies Depression Scale (CES-D), Edinburgh Postnatal Depression Scale (EPDS), The Short Form 36 Health Survey (SF-36) and Hospital Anxiety and Depression Scale (HADS).

\section{Study Design, Information Sources, and Search Strategy}

To perform this review, the SPORTDiscus, ClinicalTrials.gov, and MEDLINE (PubMed) databases were searched at the Universidad Politécnica de Madrid. The search began in October 2019 and the study was last updated between February and March 2020.

- English: exercise OR physical activity OR sport OR fitness AND pregnancy OR prenatal depression OR depression OR emotional OR emotional factors AND randomized clinical trial.

- Spanish: ejercicio O ejercicio físico O actividad física $\mathrm{O}$ deportes $\mathrm{Y}$ embarazo $\mathrm{O}$ depresión prenatal $\mathrm{O}$ depresión $\mathrm{O}$ emocional $\mathrm{O}$ factores emocionales $\mathrm{Y}$ ensayo clínico aleatorizado.

\section{Study Selection}

The inclusion criteria of the studies were randomized clinical trials whose intervention involved measurable or quantifiable activity or exercise (studies in which only advice to have an active pregnancy was provided were not selected), prenatal depression outcomes (depression symptoms or diagnosed depression) measured, and different characteristics of an exercise program provided. The selection process followed for the reviewed articles is captured in Figure 1 (Page et al., 2021).

Regarding the parameters studied, prenatal maternal depression expressed quantitatively (scale) and/or categorically (maternal depression yes/no) was the primary outcome extracted from the included studies. To determine the extent of the effects of exercise on the health of pregnant women, other pregnancy outcomes were examined as secondary outcomes (sociodemographic and physiological maternal variables and newborn outcomes, among others).

The data extracted from each of the included studies were the author(s) and publication year, country in which the study was conducted, number of participants, details of the type of exercise program, primary and secondary variable(s) analyzed and cointervention, if applicable (Table 1).

\section{Statistical Analysis}

Meta-analysis was performed separately by a different expression of depression variable. First, when the depression variable was expressed as a continuous variable, such as a score obtained by a questionnaire, the overall confidence interval (CI) was calculated using the standardized mean difference (Hedges et al., 2010).

Second, when depression was expressed as a categorical variable (yes/no), the number of events present in each study group and its relative risk (RR) were recorded, and the total sum of the RR was calculated using a random effects model (Higgins and Thompson, 2002).

In both analyses (dichotomous and continuous) the compensated average was established by assigning each study a weight relative to its sample size or number of events that contributed to the entire study (weight) or, in short, the information burden that each of them contributes. To quantify the heterogeneity present in the results, the $I^{2}$ statistic was used, which indicates the proportion of variability observed in the effect of the intervention (between studies) that is due to the heterogeneity between studies and is not random. The following thresholds were used for the $I^{2}$ statistic: low $=25 \%$, moderate $=50 \%$, and high $=75 \%$ (Daley et al., 2018).

One approach previously used to solve the problem of high heterogeneity has been to split the studies into subgroups based on some characteristics that could explain the variability of the studies (Ferreira González et al., 2011). However, in our case, given the limited number of the studies identified for the review, we have opted to present all of the examined studies in each analysis as we understand that this approach provides a more comprehensive view of the study.

\section{Quality of Evidence Assessment and Risk of Bias}

Despite being often mistaken as interchangeable terms, "quality" and "risk of bias" are, in fact, distinct but related concepts that should, thus, be differently addressed (Gunnell et al., 2020). In the present study, the assessment of quality (i.e., the degree to which studies are conducted in alignment with the highest possible standards) was performed by means of the Grading of Recommendations Assessment, Development and Evaluation (GRADE) technique (Guyatt et al., 2008), and studies that were rated as having high or moderate quality were included.

On the other hand, risk of bias (i.e., the degree to which potential biases may have led to underestimation or overestimation of an effect) was assessed following the Cochrane Handbook (Higgins et al., 2020). 
TABLE 1 | Characteristics of the studies analyzed.

\begin{tabular}{|c|c|c|c|c|c|c|c|c|c|c|c|}
\hline \multirow{2}{*}{$\begin{array}{l}\text { Author, year, } \\
\text { and country }\end{array}$} & \multirow[t]{2}{*}{ N; IG; CG } & \multicolumn{7}{|c|}{ Intervention Physical exercise program } & \multirow{2}{*}{$\begin{array}{l}\text { Main variables } \\
\text { analyzed }\end{array}$} & \multirow{2}{*}{$\begin{array}{l}\text { Secondary variables } \\
\text { analyzed }\end{array}$} & \multirow[t]{2}{*}{ Co-intervention } \\
\hline & & w Freq. & Int. & Time & Type & Sup. & Duration & Adh. & & & \\
\hline $\begin{array}{l}\text { Daley et al. (2018) } \\
\text { (United Kingdom) }\end{array}$ & $784 ; 391 ; 393$ & 2 & Mod & $30 \mathrm{~min}$ & Aerobic & Yes & 8 weeks & - & $\begin{array}{l}\text { Prenatal and postnatal } \\
\text { depression }\end{array}$ & $\begin{array}{l}\text { Maternal parameters } \\
\text { and smoking }\end{array}$ & $\begin{array}{l}\text { Smoking cessation and } \\
\text { mental health treatment }\end{array}$ \\
\hline $\begin{array}{l}\text { Vargas-Terrones et al. } \\
\text { (2019) (Spain) }\end{array}$ & $124 ; 70 ; 54$ & 3 & Mod & $60 \mathrm{~min}$ & $\begin{array}{l}\text { Aerobic }+ \text { strength }+ \\
\text { balance }+ \text { pelvic floor }+ \\
\text { stretching + relaxation }\end{array}$ & Yes & $\begin{array}{l}22-26 \\
\text { weeks }\end{array}$ & $69.3 \%$ & $\begin{array}{l}\text { Prenatal depression } \\
\text { and maternal } \\
\text { parameters }\end{array}$ & $\begin{array}{l}\text { Habits before } \\
\text { pregnancy }\end{array}$ & Basic prenatal care \\
\hline $\begin{array}{l}\text { Haakstad et al. (2016) } \\
\text { (Norway) }\end{array}$ & $105 ; 52 ; 53$ & 2 & Mod & $60 \mathrm{~min}$ & $\begin{array}{l}\text { Aerobic }+ \text { strength }+ \\
\text { relaxation }\end{array}$ & Yes & 12 weeks & $80 \%$ & $\begin{array}{l}\text { Prenatal depression } \\
\text { and regular physical } \\
\text { exercise }\end{array}$ & $\begin{array}{l}\text { Sociodemographic } \\
\text { variables, habits, and } \\
\text { complications during } \\
\text { pregnancy }\end{array}$ & No \\
\hline $\begin{array}{l}\text { Perales et al. (2016) } \\
\text { (Spain) }\end{array}$ & $241 ; 120 ; 121$ & 3 & Mod & $55-60 \mathrm{~min}$ & $\begin{array}{l}\text { Aerobic }+ \\
\text { strength }+ \text { stretching }+ \\
\text { relaxation }\end{array}$ & Yes & $\sim 30$ weeks & $90 \pm 8 \%$ & $\begin{array}{l}\text { Maternal variables, } \\
\text { hypertension, and } \\
\text { excessive weight gain }\end{array}$ & $\begin{array}{l}\text { Prenatal depression } \\
\text { and diabetes }\end{array}$ & No \\
\hline $\begin{array}{l}\text { Uebelacker et al. (2016) } \\
\text { (United States) }\end{array}$ & $20 ; 12 ; 8$ & 1 & Mod & $75 \mathrm{~min}$ & Yoga & Yes & 9 weeks & $80 \%$ & $\begin{array}{l}\text { Quality of life and } \\
\text { prenatal depression }\end{array}$ & $\begin{array}{l}\text { Sociodemographic } \\
\text { variables and maternal } \\
\text { parameters }\end{array}$ & Yoga practice at home \\
\hline $\begin{array}{l}\text { Davis et al. (2015) } \\
\text { (United States) }\end{array}$ & $46 ; 23 ; 23$ & 1 & Mod & $75 \mathrm{~min}$ & Yoga & Yes & 8 weeks & - & $\begin{array}{l}\text { Prenatal depression } \\
\text { and anxiety }\end{array}$ & Maternal parameters & No \\
\hline $\begin{array}{l}\text { Perales et al. (2015) } \\
\text { (Spain) }\end{array}$ & $106 ; 52 ; 54$ & 3 & $\begin{array}{l}\text { Low- } \\
\text { Mod }\end{array}$ & $55-60 \mathrm{~min}$ & $\begin{array}{l}\text { Stretching + aerobic }+ \\
\text { relaxation }\end{array}$ & Yes & $\sim 30$ weeks & $85 \%$ & $\begin{array}{l}\text { Prenatal depression } \\
\text { and maternal } \\
\text { parameters }\end{array}$ & $\begin{array}{l}\text { Habits in pregnancy } \\
\text { and sociodemographic } \\
\text { variables }\end{array}$ & No \\
\hline $\begin{array}{l}\text { Ussher et al. (2015) } \\
\text { (United Kingdom) }\end{array}$ & $785 ; 392 ; 393$ & 2 & Mod & $30 \mathrm{~min}$ & Aerobic & Yes & 8 weeks & $88.5 \%$ & Prenatal depression & Maternal parameters & No \\
\hline $\begin{array}{l}\text { Perales et al. (2014) } \\
\text { (Spain) }\end{array}$ & $167 ; 90 ; 77$ & 3 & $\begin{array}{l}\text { Low- } \\
\text { Mod }\end{array}$ & $55-60 \mathrm{~min}$ & $\begin{array}{l}\text { Aerobic }+ \text { strength }+ \\
\text { stretching }+ \text { relaxation }\end{array}$ & Yes & $\sim 30$ weeks & $85 \%$ & Prenatal depression & $\begin{array}{l}\text { Sociodemographic and } \\
\text { maternal variables and } \\
\text { new-born outcomes }\end{array}$ & No \\
\hline $\begin{array}{l}\text { Field et al. (2013b) } \\
\text { (United States) }\end{array}$ & $92 ; 46 ; 46$ & 1 & Mod & $20 \mathrm{~min}$ & Yoga & No & 12 weeks & - & $\begin{array}{l}\text { Prenatal, postnatal } \\
\text { depression, and anxiety }\end{array}$ & $\begin{array}{l}\text { Cortisol, estriol, and } \\
\text { progesterone levels }\end{array}$ & No \\
\hline $\begin{array}{l}\text { Field et al. (2013a) } \\
\text { (United States) }\end{array}$ & $92 ; 46 ; 46$ & 1 & Mod & $20 \mathrm{~min}$ & Tai chi/Yoga & Yes & 12 weeks & - & $\begin{array}{l}\text { Depression and anxiety } \\
\text { during pregnancy }\end{array}$ & $\begin{array}{l}\text { Psychotic disorders } \\
\text { and sleep } \\
\text { complications in } \\
\text { pregnancy }\end{array}$ & No \\
\hline $\begin{array}{l}\text { Satyapriya et al. (2013) } \\
\text { (India) }\end{array}$ & $96 ; 51 ; 45$ & 7 & Mod & $60 \mathrm{~min}$ & Yoga & Yes & 16 weeks & - & $\begin{array}{l}\text { Maternal parameters, } \\
\text { prenatal depression, } \\
\text { and anxiety }\end{array}$ & $\begin{array}{l}\text { Sociodemographic } \\
\text { variables }\end{array}$ & No \\
\hline $\begin{array}{l}\text { Field et al., } 2012 \\
\text { (United States) }\end{array}$ & $84 ; 28 ; 28-28$ & 2 & Mod & $20 \mathrm{~min}$ & Yoga & Yes & 12 weeks & $80 \%$ & $\begin{array}{l}\text { Depression and anxiety } \\
\text { during pregnancy }\end{array}$ & Legs and back pain & No \\
\hline $\begin{array}{l}\text { Robledo-Colonia et al. } \\
\text { (2012) (Colombia) }\end{array}$ & $80 ; 40 ; 40$ & 3 & $\begin{array}{l}\text { Mod- } \\
\text { High }\end{array}$ & $60 \mathrm{~min}$ & $\begin{array}{l}\text { Aerobic }+ \text { stretching }+ \\
\text { relaxation }\end{array}$ & Yes & 12 weeks & - & Depressive symptoms & $\begin{array}{l}\text { Sociodemographic } \\
\text { variables }\end{array}$ & $\begin{array}{l}\text { Physiotherapy } \\
\text { treatment }\end{array}$ \\
\hline $\begin{array}{l}\text { Mosquera-Valderrama et al. } \\
\text { (2012) (Colombia) }\end{array}$ & $74 ; 37 ; 37$ & 3 & Mod & $50 \mathrm{~min}$ & Aerobic + stretching & Yes & 12 weeks & - & Depressive symptoms & $\begin{array}{l}\text { Sociodemographic } \\
\text { variables }\end{array}$ & $\begin{array}{l}\text { Walks twice a week } \\
\text { unsupervised }\end{array}$ \\
\hline
\end{tabular}

Rf, reference; RCT, randomized controlled trial; IG, intervention group; CG, control group; W freq., weekly frequency; Int., intensity; Mod, moderate; Sup., supervised sessions; Adh., adherence. 


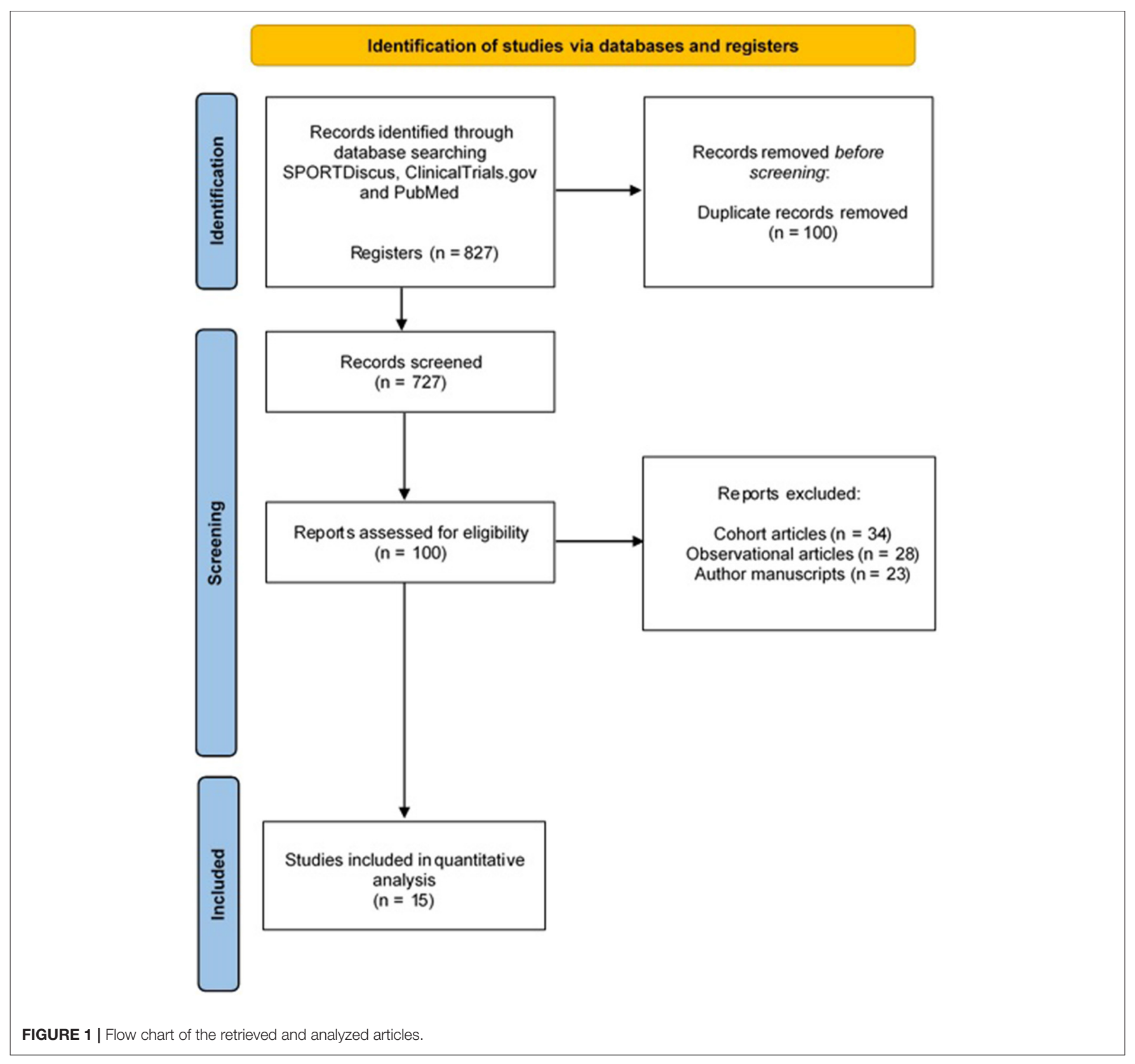

\section{RESULTS}

From a total of 827 retrieved articles, 727 were excluded for not meeting any of the inclusion criteria (Figure 1). In addition, 85 articles were excluded because they were not completely randomized clinical trials (i.e., they lacked a randomization process). Finally, 15 studies were included for analysis. Thirteen of them reported participants' depression or depression symptoms as a continuous variable (i.e., a score obtained in a questionnaire), and these studies are presented in Figure 2. On the other hand, in eight of them, depression was treated as a categorical variable reporting the number of women showing depression symptoms in each group (control and intervention). These studies are displayed in Figure 3. Last, six studies reported information about depression as both a continuous variable (score obtained in a questionnaire) and a dichotomous variable (suffering/not suffering depression). These works have, thus, been included in both Figures 2, 3 (Perales et al., 2014, 2015; Ussher et al., 2015; Haakstad et al., 2016; Uebelacker et al., 2016; Daley et al., 2018).

Among the 15 articles included in the meta-analysis, 14 included sessions supervised by professionals in the field. The exercise sessions (both supervised and not) were designed for low-to-moderate intensity or moderate-to-high intensity exercise and were not performed more than three times per week. The session durations varied from 20 to a maximum of $75 \mathrm{~min}$ for a session. 


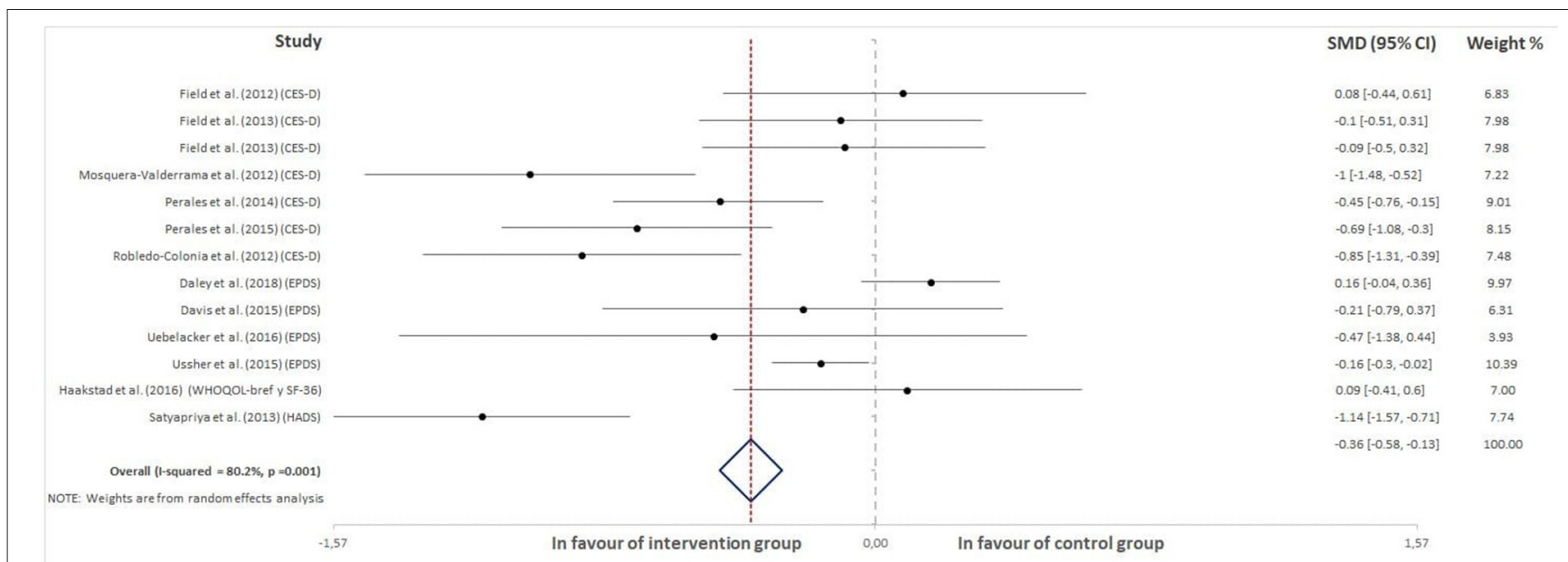

FIGURE 2 | Effect of exercise on the score obtained for the participants on the administered questionnaires.

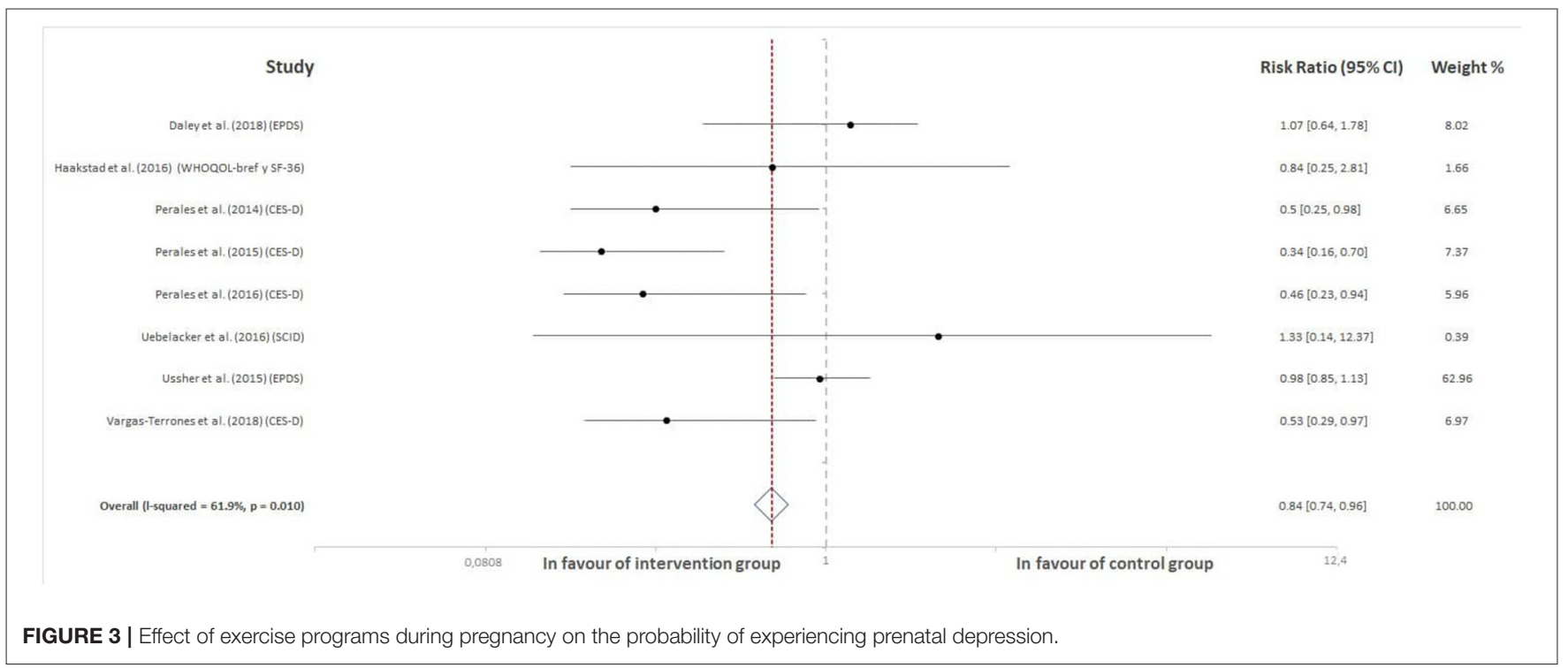

\section{Effect of Exercise on the Score Obtained for the Participants on the Administered Questionnaires}

Thirteen studies were included in this analysis. The results revealed a negative association between exercise practice during pregnancy and the scores obtained for the questionnaires that were used to measure depression in pregnant women ( $\mathrm{ES}=-0.36,95 \% \mathrm{CI}=-0.58,-13$, $\left.I^{2}=80.2 \%, P_{\text {heterogeneity }}=0.001\right)$. Figure 2 shows the forest plot corresponding to the present meta-analysis.

\section{Effect of Exercise on the Number and Percentage of Depressed Pregnant Women in the Study Groups}

A total of eight studies were included in this analysis. The global effect of exercise was evident in the number and percentage of pregnant women when those who were considered depressed in the intervention groups were compared with those in the control groups. Specifically, the total RR compensated was 0.84 $\left(95 \% \mathrm{CI}=0.74,0.96, I^{2}=61.9 \%, \mathrm{P}_{\text {heterogeneity }}=0.010\right)$. These outcomes indicate that women who remain inactive present a $16 \%$ greater probability of experiencing prenatal depression. Figure 3 shows the forest plot corresponding to the present meta-analysis.

\section{Risk of Bias Assessment}

Overall, the quality of evidence ranged from low to high (see Figure 4; Table 2).

Most of the studies exhibited low selection and attrition bias. There was a reasonable number of studies whose risk of detection bias was found to be unclear because studies reported whether outcome assessors had not been blinded to participants. The most common sources of risk of bias were (a) 

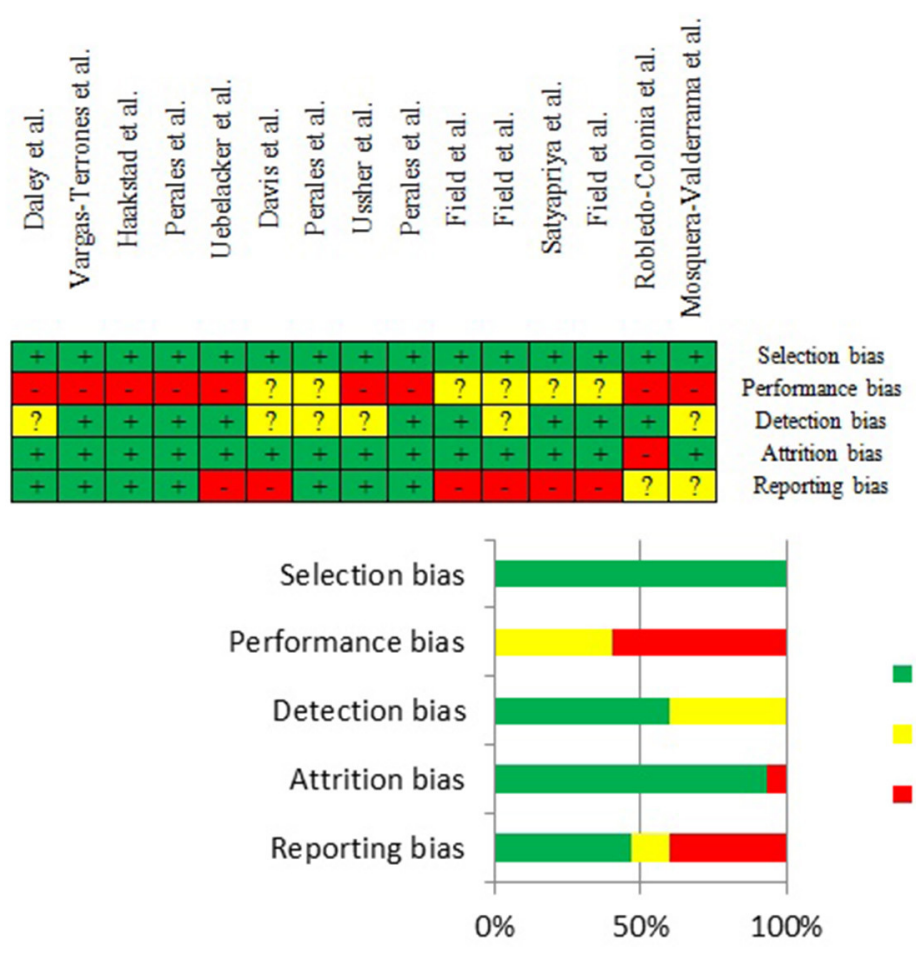

\author{
- Low risk of bias \\ Unclear risk of bias \\ High risk of bias
}

FIGURE 4 | Risk of bias summary.

the low likelihood that either study participants or personnel were blinded to the experimental condition (performance bias) and (b) the fact that findings of some outcomes appearing in the protocol of the studies were not published in the analyzed studies (reporting bias).

Despite the risk of bias findings, it was decided to not disregard any study in our analyses. First, with regard to performance bias, because it is acknowledged in the Cochrane Collaboration's Tool (Higgins et al., 2020), blinding is not possible in certain situations (it is usually impossible to blind people to whether a PA program has been followed). Second, relating to the reporting bias, based on data extracted from the included studies, it is unlikely that the remaining outcomes of interest (biological rather than social data) were significantly associated with depression.

\section{DISCUSSION}

The present study aimed to determine the effects of exercise during pregnancy on maternal prenatal depression. The results show a trend toward a small reduction in both the scores of the instruments (questionnaires) that measured the prevalence of depressive symptoms in pregnant women and the number and percentage of women with diagnosed prenatal depression in the intervention groups (physical exercise). It is important to clarify that, during pregnancy, a woman may present depressive symptoms and increased emotional lability but not be diagnosed with prenatal depression although obviously both conditions are closely associated.

Because all the studies investigated healthy pregnant women, the results obtained in these studies are related to depressive symptoms rather than to diagnosed depression. Therefore, from a global perspective, the findings of the present study could be used and have an important clinical application to prescribe groups and supervised exercise during pregnancy as a preventive factor against emotional lability and associated complications. The results of the present study allow us to conclude that supervised exercise during pregnancy constitutes a powerful tool for preventing and reducing prenatal depression.

Regarding the impact of exercise during pregnancy, the results suggest that there is a positive association between an active pregnancy and a more balanced and adequate emotional state. Because depressive symptoms begin early in pregnancy (first trimester), the supervised exercise program designed for healthy pregnant women should also begin early, once it is known that there are no obstetric contraindications to exercise during pregnancy.

The study designed by Perales et al. (2014) deserves particular attention; the article included 167 pregnant women and noted that, although depression levels were similar in both groups (slightly higher in the intervention group) at the beginning of pregnancy, by the end of pregnancy there was a significant difference (reduction) in favor of the intervention group (exercise) compared with the control group in relation to both the questionnaire values (CES-D questionnaire) and 
TABLE 2 | Risk of bias of reviewed studies.

\begin{tabular}{|c|c|c|c|c|c|c|c|c|c|c|}
\hline \multirow[t]{2}{*}{ Articles/Bias } & \multicolumn{2}{|r|}{ Selection bias } & \multicolumn{2}{|r|}{ Performance bias } & \multicolumn{2}{|r|}{ Detection bias } & \multicolumn{2}{|r|}{ Attrition bias } & \multicolumn{2}{|r|}{ Reporting bias } \\
\hline & Risk & Text where it is located & Risk & Text where it is located & Risk & Text where it is located & Risk & Text where it is located & Risk & Text where it is located \\
\hline Daley et al. (2018) & Low & $\begin{array}{l}\text { "At the first session, } \\
\text { participants were randomly } \\
\text { assigned } \\
\text { (based on a } \\
\text { computer-generated } \\
\text { code)..." }\end{array}$ & High & $\begin{array}{l}\text { "It was not feasible to mask } \\
\text { participants or researchers } \\
\text { to group allocation." }\end{array}$ & Unc. & $\begin{array}{l}\text { "...higher self-reports of } \\
\text { activity in the physical } \\
\text { activity group compared } \\
\text { with the control group may } \\
\text { be biased by knowledge of } \\
\text { allocation." }\end{array}$ & Low & $\begin{array}{l}\text { "When using an intention to } \\
\text { treat approach it } \\
\text { is acceptable to exclude } \\
\text { patients' data, without } \\
\text { risking bias..." }\end{array}$ & Low & $\begin{array}{l}\text { The study protocol is } \\
\text { available and all of the } \\
\text { study's pre-specified } \\
\text { (primary and secondary) } \\
\text { outcomes that are of } \\
\text { interest in the review have } \\
\text { been reported. }\end{array}$ \\
\hline $\begin{array}{l}\text { Vargas-Terrones } \\
\text { et al. (2019) }\end{array}$ & Low & $\begin{array}{l}\text { "A simple randomization } \\
\text { was performed with the } \\
\text { Epidat V.3.1 } \\
\text { program to allocate the } \\
\text { participants into two groups } \\
\text { in order of entry: } \\
\text { intervention group (IG) and } \\
\text { control group (CG)." }\end{array}$ & High & $\begin{array}{l}\text { The nature of the } \\
\text { intervention prevented the } \\
\text { study from blinding } \\
\text { participants. }\end{array}$ & Low & $\begin{array}{l}\text { "Participants were not } \\
\text { involved in the design, } \\
\text { recruitment, and conduct of } \\
\text { the study." }\end{array}$ & Low & $\begin{array}{l}\text { "An analysis by } \\
\text { intention-to-treat was also } \\
\text { performed using two } \\
\text { different methods." }\end{array}$ & Low & $\begin{array}{l}\text { The study protocol is } \\
\text { available and all of the } \\
\text { study's pre-specified } \\
\text { (primary and secondary) } \\
\text { outcomes that are of } \\
\text { interest in the review have } \\
\text { been reported. }\end{array}$ \\
\hline $\begin{array}{l}\text { Haakstad et al. } \\
\text { (2016) }\end{array}$ & Low & $\begin{array}{l}\text { "Allocations were sealed in } \\
\text { opaque numbered } \\
\text { envelopes following a } \\
\text { simple computer-based } \\
\text { randomization program." }\end{array}$ & High & $\begin{array}{l}\text { The nature of the } \\
\text { intervention prevented the } \\
\text { study from blinding } \\
\text { participants. }\end{array}$ & Low & $\begin{array}{l}\text { "In order to treat the two } \\
\text { groups identically apart from } \\
\text { for the experimental } \\
\text { intervention, the controls } \\
\text { underwent all tests and } \\
\text { completed the same } \\
\text { interview as the exercise } \\
\text { group, also with respect to } \\
\text { assessment of total physical } \\
\text { activity level and exercise } \\
\text { habits." }\end{array}$ & Low & $\begin{array}{l}\text { "The principal analysis was } \\
\text { done on an intention to treat } \\
\text { basis..." }\end{array}$ & Low & $\begin{array}{l}\text { The study protocol is } \\
\text { available and all of the } \\
\text { study's pre-specified } \\
\text { (primary and secondary) } \\
\text { outcomes that are of } \\
\text { interest in the review have } \\
\text { been reported. }\end{array}$ \\
\hline $\begin{array}{l}\text { Perales et al. } \\
\text { (2016) }\end{array}$ & Low & $\begin{array}{l}\text { "Thereafter, they were } \\
\text { randomly assigned to a } \\
\text { standard care (control, initial } \\
n=121 \text { ) or intervention } \\
\text { group } \\
\text { (exercise, } n=120 \text { ) using a } \\
\text { computer-generated list of } \\
\text { random } \\
\text { Numbers." }\end{array}$ & High & $\begin{array}{l}\text { "The study participants and } \\
\text { the qualified fitness } \\
\text { instructors who supervised } \\
\text { the exercise sessions were } \\
\text { not blinded to the group } \\
\text { allocation." }\end{array}$ & Low & $\begin{array}{l}\text { "The researchers } \\
\text { responsible for assessing } \\
\text { eligibility, baseline } \\
\text { measures, or outcome } \\
\text { assessment were blinded to } \\
\text { the group allocation. }\end{array}$ & Low & $\begin{array}{l}\text { "All the analyses were } \\
\text { performed using the } \\
\text { Statistical Package for } \\
\text { Social Sciences program } \\
\text { version 22.0, and were } \\
\text { adhered to the } \\
\text { intention-to-treat } \\
\text { principle..." }\end{array}$ & Low & $\begin{array}{l}\text { The study protocol is } \\
\text { available and all of the } \\
\text { study's pre-specified } \\
\text { (primary and secondary) } \\
\text { outcomes that are of } \\
\text { interest in the review have } \\
\text { been reported. }\end{array}$ \\
\hline $\begin{array}{l}\text { Uebelacker et al. } \\
\text { (2016) }\end{array}$ & Low & $\begin{array}{l}\text { "Once we received } \\
\text { clearance, we re-contacted } \\
\text { the participant and } \\
\text { randomized her to the } \\
\text { prenatal yoga program } \\
\text { (PYP) or a perinatal health } \\
\text { education control } \\
\text { condition." }\end{array}$ & High & $\begin{array}{l}\text { "Because this is a study of } \\
\text { behavioral interventions, } \\
\text { participants could not be } \\
\text { blind to which intervention } \\
\text { they received." }\end{array}$ & Low & $\begin{array}{l}\text { "Study groups did not differ } \\
\text { on any variables." }\end{array}$ & Low & No missing data. & High & Cannot locate protocol. \\
\hline
\end{tabular}


TABLE 2 | Continued

\begin{tabular}{|c|c|c|c|c|c|c|c|c|c|c|}
\hline \multirow[t]{2}{*}{ Articles/Bias } & \multicolumn{2}{|r|}{ Selection bias } & \multicolumn{2}{|r|}{ Performance bias } & \multicolumn{2}{|r|}{ Detection bias } & \multicolumn{2}{|r|}{ Attrition bias } & \multicolumn{2}{|r|}{ Reporting bias } \\
\hline & Risk & Text where it is located & Risk & Text where it is located & Risk & Text where it is located & Risk & Text where it is located & Risk & Text where it is located \\
\hline Davis et al. (2015) & Low & $\begin{array}{l}\text { "Participants in both } \\
\text { conditions completed a } \\
\text { clinical interview and } \\
\text { baseline self-report } \\
\text { questionnaires prior to } \\
\text { randomization." }\end{array}$ & Unc. & $\begin{array}{l}\text { "Interrater reliability for the } \\
\text { Yoga Adherence Scale was } \\
98 \% \text { for the four classes } \\
\text { that both research } \\
\text { assistants evaluated." }\end{array}$ & Unc. & $\begin{array}{l}\text { There is no evidence about } \\
\text { blinding of outcomes, but } \\
\text { everything suggests that it is } \\
\text { done. }\end{array}$ & Low & No missing data. & High & Cannot locate protocol. \\
\hline $\begin{array}{l}\text { Perales et al. } \\
\text { (2015) }\end{array}$ & Low & $\begin{array}{l}\text { "A computer-generated list } \\
\text { of random numbers was } \\
\text { used to allocate the } \\
\text { participants into the } \\
\text { groups." }\end{array}$ & Unc. & $\begin{array}{l}\text { "The randomization blinded } \\
\text { process } \\
\text { (sequence generation, } \\
\text { allocation concealment, and } \\
\text { implementation) was } \\
\text { performed by three different } \\
\text { authors." }\end{array}$ & Unc. & $\begin{array}{l}\text { There is no evidence about } \\
\text { blinding of outcomes, but } \\
\text { everything suggests that it is } \\
\text { done. }\end{array}$ & Low & No missing data. & Low & $\begin{array}{l}\text { The study protocol is } \\
\text { available and all of the } \\
\text { study's pre-specified } \\
\text { (primary and secondary) } \\
\text { outcomes that are of } \\
\text { interest in the review have } \\
\text { been reported. }\end{array}$ \\
\hline $\begin{array}{l}\text { Ussher et al. } \\
\text { (2015) }\end{array}$ & Low & $\begin{array}{l}\text { "An independent statistician } \\
\text { generated a randomization } \\
\text { list using Stata, with random } \\
\text { permuted blocks of random } \\
\text { size stratified by recruitment } \\
\text { cente, in a 1:1 ratio." }\end{array}$ & High & $\begin{array}{l}\text { "It was not feasible to mask } \\
\text { participants or researchers } \\
\text { to group allocation." }\end{array}$ & Unc. & $\begin{array}{l}\text { There is no evidence about } \\
\text { blinding of outcomes, but } \\
\text { everything suggests that it is } \\
\text { done. }\end{array}$ & Low & $\begin{array}{l}\text { "Analysis was on an } \\
\text { intention to treat basis..." }\end{array}$ & Low & $\begin{array}{l}\text { The study protocol is } \\
\text { available and all of the } \\
\text { study's pre-specified } \\
\text { (primary and secondary) } \\
\text { outcomes that are of } \\
\text { interest in the review have } \\
\text { been reported. }\end{array}$ \\
\hline $\begin{array}{l}\text { Perales et al. } \\
\text { (2014) }\end{array}$ & Low & $\begin{array}{l}\text { "For allocation of the } \\
\text { participants, a } \\
\text { computer-generated list of } \\
\text { random numbers was } \\
\text { used." }\end{array}$ & High & $\begin{array}{l}\text { "...due type of intervention } \\
\text { blinding of participants was } \\
\text { not possible." }\end{array}$ & Low & $\begin{array}{l}\text { "Randomization process } \\
\text { (sequence generation, } \\
\text { allocation concealment, and } \\
\text { implementation) was made } \\
\text { for three different authors in } \\
\text { order to facilitate blinding of } \\
\text { process and outcomes } \\
\text { assessment." }\end{array}$ & Low & No missing data. & Low & $\begin{array}{l}\text { The study protocol is } \\
\text { available and all of the } \\
\text { study's pre-specified } \\
\text { (primary and secondary) } \\
\text { outcomes that are of } \\
\text { interest in the review have } \\
\text { been reported. }\end{array}$ \\
\hline Field et al. (2013a) & Low & $\begin{array}{l}\text { "...the depressed pregnant } \\
\text { women were randomly } \\
\text { assigned to a yoga or a } \\
\text { social support group based } \\
\text { on a random numbers } \\
\text { table." }\end{array}$ & Unc. & $\begin{array}{l}\text { "...by trained researchers } \\
\text { who were blinded to the } \\
\text { group assignment and the } \\
\text { study hypotheses. }\end{array}$ & Low & $\begin{array}{l}\text { "The groups did not differ } \\
\text { on demographic variables } \\
\text { and baseline measures. }\end{array}$ & Low & No missing data. & High & Cannot locate protocol. \\
\hline Field et al. (2013b) & Low & $\begin{array}{l}\text { "The participants were } \\
\text { clinically depressed } \\
\text { pregnant women who were } \\
\text { randomly assigned to either } \\
\text { a tai chi/yoga treatment or a } \\
\text { control group." }\end{array}$ & Unc. & $\begin{array}{l}\text { The nature of the } \\
\text { intervention prevented the } \\
\text { study from blinding } \\
\text { participants. }\end{array}$ & Unc. & $\begin{array}{l}\text { There is no evidence about } \\
\text { blinding of outcomes, but } \\
\text { everything suggests that it is } \\
\text { done. }\end{array}$ & Low & No missing data. & High & Cannot locate protocol. \\
\hline
\end{tabular}


TABLE 2 | Continued

\begin{tabular}{|c|c|c|c|c|c|c|c|c|c|c|}
\hline \multirow[t]{2}{*}{ Articles/Bias } & \multicolumn{2}{|r|}{ Selection bias } & \multicolumn{2}{|r|}{ Performance bias } & \multicolumn{2}{|r|}{ Detection bias } & \multicolumn{2}{|r|}{ Attrition bias } & \multicolumn{2}{|r|}{ Reporting bias } \\
\hline & Risk & Text where it is located & Risk & Text where it is located & Risk & Text where it is located & Risk & Text where it is located & Risk & Text where it is located \\
\hline $\begin{array}{l}\text { Satyapriya et al. } \\
\text { (2013) }\end{array}$ & Low & $\begin{array}{l}\text { "...the subjects were } \\
\text { allocated to two groups } \\
\text { (yoga and control) using a } \\
\text { computer generated } \\
\text { random number..." }\end{array}$ & Unc. & $\begin{array}{l}\text { As this was an interventional } \\
\text { study, the participants or the } \\
\text { trainer could not be blinded. } \\
\text { Attempts were made to } \\
\text { mask wherever feasible to } \\
\text { reduce the bias. }\end{array}$ & Low & $\begin{array}{l}\text { "The team who did the } \\
\text { assessments was not } \\
\text { involved in administering the } \\
\text { intervention. The statistician } \\
\text { who did the randomization } \\
\text { and analysis was blind to } \\
\text { the source of the data." }\end{array}$ & Low & No missing data. & High & Cannot locate protocol. \\
\hline Field et al. (2012) & Low & $\begin{array}{l}\text { "The women were then } \\
\text { randomly assigned to a } \\
\text { yoga, massage therapy or } \\
\text { standard prenatal care } \\
\text { control group." }\end{array}$ & Unc. & $\begin{array}{l}\text { "All assessments were } \\
\text { conducted by the trained } \\
\text { research associates who } \\
\text { were blind to the study' } \\
\text { hypotheses and to the } \\
\text { group assignment." }\end{array}$ & Low & $\begin{array}{l}\text { "In addition, the yoga and } \\
\text { massage therapy groups } \\
\text { did not differ on neonatal } \\
\text { outcomes including } \\
\text { gestational age and } \\
\text { birthweight." }\end{array}$ & High & $\begin{array}{l}\text { There are missing data } \\
\text { (more than } 10 \% \text { of sample). }\end{array}$ & High & Cannot locate protocol. \\
\hline $\begin{array}{l}\text { Robledo-Colonia } \\
\text { et al. (2012) }\end{array}$ & Low & $\begin{array}{l}\text { "Randomization was } \\
\text { performed using a permuted } \\
\text { block design with a block si } \\
\text { e of } 10 \text { and exp:con ratios } \\
\text { of } 5: 5 \text {, } \\
6: 4 \text { or } 4: 6 . "\end{array}$ & High & $\begin{array}{l}\text { "Participants and therapists } \\
\text { administering the } \\
\text { intervention were not } \\
\text { blinded." }\end{array}$ & Low & $\begin{array}{l}\text { "The investigators } \\
\text { responsible for outcome } \\
\text { assessment were blinded to } \\
\text { group allocation." }\end{array}$ & Low & $\begin{array}{l}\text { "Analysis was according to } \\
\text { the principle of } \\
\text { intention-to-treat." }\end{array}$ & Unc. & $\begin{array}{l}\text { The variables don't coincide } \\
\text { in the protocol and in the } \\
\text { article methodology. }\end{array}$ \\
\hline $\begin{array}{l}\text { Mosquera- } \\
\text { Valderrama et al. } \\
\text { (2012) }\end{array}$ & Low & $\begin{array}{l}\text { "Después de la realización } \\
\text { de estas pruebas, las } \\
\text { pacientes } \\
\text { fueron asignadas } \\
\text { aleatoriamente." }\end{array}$ & High & $\begin{array}{l}\text { "La principal limitación es } \\
\text { que los terapeutas de } \\
\text { campo y las participantes } \\
\text { no pueden ser cegados a } \\
\text { las intervenciones con el } \\
\text { entrenamiento físico } \\
\text { aeróbico." }\end{array}$ & Unc. & $\begin{array}{l}\text { There is no evidence about } \\
\text { blinding of outcomes, but } \\
\text { everything suggests that it is } \\
\text { done. }\end{array}$ & Low & $\begin{array}{l}\text { “...destacamos la validez } \\
\text { de los hallazgos debido al } \\
\text { diseño del estudio, que } \\
\text { incorpora varias } \\
\text { características que } \\
\text { minimizan la posibilidad de } \\
\text { sesgo en los resultados, } \\
\text { tales como la aleatorización, } \\
\text { y el análisis de intención de } \\
\text { tratamiento." }\end{array}$ & $\begin{array}{l}\text { Unc. } \\
\text {, }\end{array}$ & $\begin{array}{l}\text { The variables don't coincide } \\
\text { in the protocol and in the } \\
\text { article methodology. }\end{array}$ \\
\hline
\end{tabular}


the number and percentage of pregnant women considered depressed. Overall, this result confirms the positive impact of a supervised exercise program during pregnancy on the emotional state of pregnant women.

It is interesting to analyze what factors present in exercise programs can be associated with the emotional response of pregnant women and determine an improvement in emotional state. In this sense, we find that both the supervision of exercise by a professional and the adherence of the participants to the program were relevant factors to increase the positive impact of exercise on improving emotional state. This positive association between exercise and the prevention of maternal prenatal depression has been demonstrated by some studies with supervised exercise programs and high adherence of the participants (Field et al., 2012; Perales et al., 2014, 2015, 2016; Ussher et al., 2015; Haakstad et al., 2016; Uebelacker et al., 2016; Vargas-Terrones et al., 2019).

The other important aspects seem to include the type of exercise and the activities implemented in the sessions. Thus, some studies include a combined practice with mixed activities (aerobic resistance, muscle strengthening, coordination, pelvic floor, flexibility) and show good results (Mosquera-Valderrama et al., 2012; Robledo-Colonia et al., 2012; Perales et al., 2014, 2015, 2016; Haakstad et al., 2016; Vargas-Terrones et al., 2019). Additionally, there was a reduction in prenatal depression in studies that used yoga (Davis et al., 2015) or tai-chi (Field et al., 2013a) as an intervention program; however, it is important to highlight that there is no absolute consensus as to which type of exercise reduces these symptoms the most.

In a recent RS-MA, Davenport et al. (2018) found a positive influence of supervised exercise on the reduction of depressive symptoms during pregnancy. Similarly, there are other recent systematic reviews that conclude that supervised exercise with low-to-moderate intensity is a preventive measure against postpartum depression as well as gestational depression (Shivakumar et al., 2011; Daley et al., 2015; Gong et al., 2015).

As it is been shown that women who were inactive during pregnancy were $16 \%$ more likely to suffer prenatal depression, future studies will focus on comparing the effect of

\section{REFERENCES}

Austin, M. P., Priest, S. R., and Sullivan, E. A. (2008). Antenatal psychosocial assessment for reducing perinatal mental health morbidity. Cochrane Database Syst. Rev. Cd005124. doi: 10.1002/14651858.CD005124.pub2

Barakat, R. (2006). El ejercicio físico durante el embarazo. Madrid: Pearson Alhambra.

Barakat, R., Díaz-Blanco, A., Franco, E., Rollán-Malmierca, A., Brik, M., Vargas, M., et al. (2019). Guías clínicas para el ejercicio físico durante el embarazo. Prog. Obstet. Gynecol. 62, 464-471. doi: 10.20960/j.pog.00231

Barakat, R., Pelaez, M., Cordero, Y., Perales, M., Lopez, C., Coteron, J., et al. (2016). Exercise during pregnancy protects against hypertension and macrosomia: randomized clinical trial. Am. J. Obstet. Gynecol. 214, 649.e1-649.e8. doi: 10.1016/j.ajog.2015.11.039

Barakat, R., Perales, M., Garatachea, N., Ruiz, J. R., and Lucia, A. (2015). Exercise during pregnancy. A narrative review asking: what do we antidepressants during pregnancy with exercise during the same period. However, more studies examining the effect of exercise during pregnancy are needed to contribute to understanding our research question.

The limitations of this study were the scarcity of scientific literature about exercise and prenatal depression because there are more papers that study postnatal depression than prenatal depression, the lack of consensus on the depression scales used (there were four different scales with four different measured scores), and the variability of the exercise programs performed in all studies. The results of the present study demonstrate that aerobic and supervised exercise during pregnancy could be a tool to prevent depressive symptoms as well as diagnosed prenatal depression.

\section{DATA AVAILABILITY STATEMENT}

The original contributions presented in the study are included in the article/supplementary material, further inquiries can be directed to the corresponding author.

\section{AUTHOR CONTRIBUTIONS}

MS-P was responsible for the design of the review study, contributed to the data selection and analysis, and the preparation of the manuscript. EF led data selection and analysis and contributed to manuscript writing. CS-J and JG-A contributed to the data selection and analysis. JP-T contributed to the data selection and analysis and the preparation of the manuscript. RB contributed to the design of the study and the manuscript writing. IR was mainly responsible for the design of the review study and the data analysis and led the manuscript writing. All authors contributed to the article and approved the submitted version.

\section{FUNDING}

This work was partially supported by the Program CSD16/UPB/19, Consejo Superior de Deportes (Ministerios de Cultura y Deporte), Spain. know? Br. J. Sports Med. 49, 1377-1381. doi: 10.1136/bjsports-2015094756

Barbour, K. A., Edenfield, T. M., and Blumenthal, J. A. (2007). Exercise as a treatment for depression and other psychiatric disorders: a review. J. Cardiopulm. Rehabil. Prev. 27, 359-367. doi: 10.1097/01.HCR.0000300262.69645.95

Bienvenu, O. J., Needham, D. M., and Hopkins, R. O. (2013). Diagnostic and statistical manual of mental disorders, and the impact of events scale-revised: response. Chest 144, 1974-1975. doi: 10.1378/chest. 13-1940

Blumenthal, J. A., Babyak, M. A., Doraiswamy, P. M., Watkins, L., Hoffman, B. M., Barbour, K. A., et al. (2007). Exercise and pharmacotherapy in the treatment of major depressive disorder. Psychosom. Med. 69, 587-596. doi: 10.1097/PSY.0b013e318148c19a

Campagne, D. M. (2004). The obstetrician and depression during pregnancy. Eur. J. Obstet. Gynecol. Reprod. Biol. 116, 125-130. doi: 10.1016/j.ejogrb.2003.11.028 
Daley, A., Riaz, M., Lewis, S., Aveyard, P., Coleman, T., Manyonda, I., et al. (2018). Physical activity for antenatal and postnatal depression in women attempting to quit smoking: randomised controlled trial. BMC Pregnancy Childbirth 18:156. doi: 10.1186/s12884-018-1784-3

Daley, A. J., Foster, L., Long, G., Palmer, C., Robinson, O., Walmsley, H., et al. (2015). The effectiveness of exercise for the prevention and treatment of antenatal depression: systematic review with meta-analysis. BJOG Int. J. Obstet. Gynaecol. 122, 57-62. doi: 10.1111/1471-0528.12909

Davenport, M. H., McCurdy, A. P., Mottola, M. F., Skow, R. J., Meah, V. L., Poitras, V. J., et al. (2018). Impact of prenatal exercise on both prenatal and postnatal anxiety and depressive symptoms: a systematic review and meta-analysis. $\mathrm{Br}$. J. Sports Med. 52, 1376-1385. doi: 10.1136/bjsports-2018-099697

Davis, K., Goodman, S. H., Leiferman, J., Taylor, M., and Dimidjian, S. (2015). A randomized controlled trial of yoga for pregnant women with symptoms of depression and anxiety. Complement. Ther. Clin. Pract. 21, 166-172. doi: $10.1016 /$ j.ctcp. 2015.06 .005

Deave, T., Heron, J., Evans, J., and Emond, A. (2008). The impact of maternal depression in pregnancy on early child development. BJOG Int. J. Obstet. Gynaecol. 115, 1043-1051. doi: 10.1111/j.1471-0528.2008.01752.x

Ertel, K. A., Koenen, K. C., Rich-Edwards, J. W., and Gillman, M. W. (2010). Antenatal and postpartum depressive symptoms are differentially associated with early childhood weight and adiposity. Paediatr. Perinat. Epidemiol. 24, 179-189. doi: 10.1111/j.1365-3016.2010.01098.x

Ferreira González, I., Urrútia, G., and Alonso-Coello, P. (2011). Systematic reviews and meta-analysis: scientific rationale and interpretation. Rev. Esp. Cardiol. 64, 688-696. doi: 10.1016/j.rec.2011.03.027

Field, T. (2011). Prenatal depression effects on early development: a review. Infant Behav. Dev. 34, 1-14. doi: 10.1016/j.infbeh.2010.09.008

Field, T., Diego, M., Delgado, J., and Medina, L. (2013a). Tai chi/yoga reduces prenatal depression, anxiety, and sleep disturbances. Complement. Ther. Clin. Pract. 19, 6-10. doi: 10.1016/j.ctcp.2012.10.001

Field, T., Diego, M., Delgado, J., and Medina, L. (2013b). Yoga and social support reduce prenatal depression, anxiety, and cortisol. J. Bodyw. Mov. Ther. 17, 397-403. doi: 10.1016/j.jbmt.2013.03.010

Field, T., Diego, M., and Hernandez-Reif, M. (2006). Prenatal depression effects on the fetus and newborn: a review. Infant Behav. Dev. 29, 445-455. doi: 10.1016/j.infbeh.2006.03.003

Field, T., Diego, M., Hernandez-Reif, M., Medina, L., Delgado, J., and Hernandez, A. (2012). Yoga and massage therapy reduce prenatal depression and prematurity. J. Bodyw. Mov. Ther. 16, 204-209. doi: 10.1016/j.jbmt.2011.08.002

Gong, H., Ni, C., Shen, X., Wu, T., and Jiang, C. (2015). Yoga for prenatal depression: a systematic review and meta-analysis. BMC Psychiatry 15:14. doi: 10.1186/s12888-015-0393-1

Goodwin, A., Astbury, J., and McMeeken, J. (2000). Body image and psychological well-being in pregnancy. A comparison of exercisers and non-exercisers. Aust. N. Z. J. Obstet. Gynaecol. 40, 442-447. doi: 10.1111/j.1479-828X.2000.tb01178.x

Grote, N. K., Bridge, J. A., Gavin, A. R., Melville, J. L., Iyengar, S., and Katon, W. J. (2010). A meta-analysis of depression during pregnancy and the risk of preterm birth, low birth weight, and intrauterine growth restriction. Arch. Gen. Psychiatry 67, 1012-1024. doi: 10.1001/archgenpsychiatry.2010.111

Gunnell, K., Poitras, V. J., and Tod, D. (2020). Questions and answers about conducting systematic reviews in sport and exercise psychology. Int. Rev. Sport Exerc. Psychol. 13, 297-318. doi: 10.1080/1750984X.2019.1695141

Guyatt, G. H., Oxman, A. D., Vist, G. E., Kunz, R., Falck-Ytter, Y., AlonsoCoello, P., et al. (2008). GRADE: an emerging consensus on rating quality of evidence and strength of recommendations. BMJ 336, 924-926. doi: 10.1136/bmj.39489.470347.AD

Haakstad, L. A., Torset, B., and Bø, K. (2016). What is the effect of regular group exercise on maternal psychological outcomes and common pregnancy complaints? an assessor blinded RCT. Midwifery 32, 81-86. doi: 10.1016/j.midw.2015.10.008

Hahn-Holbrook, J., Cornwell-Hinrichs, T., and Anaya, I. (2018). Economic and health predictors of national postpartum depression prevalence: a systematic review, meta-analysis, and meta-regression of 291 studies from 56 countries. Front. Psychiatry 8:248. doi: 10.3389/fpsyt.2017.00248

Hammond, S., and Crozier, K. (2007). Depression: assessing the causes. R. Coll. Midwives 10, 365-368.
Hay, D. F., Pawlby, S., Waters, C. S., Perra, O., and Sharp, D. (2010). Mothers' antenatal depression and their children's antisocial outcomes. Child Dev. 81, 149-165. doi: 10.1111/j.1467-8624.2009.01386.x

Hedges, L. V., Tipton, E., and Johnson, M. C. (2010). Robust variance estimation in meta-regression with dependent effect size estimates. Res. Synth. Methods 1, 39-65. doi: 10.1002/jrsm.5

Higgins, J. P., Savovíc, J., Page, M. J., Elbers, R. G., and Sterne, J. A. C. (2020). "Chapter 8: assessing risk of bias in a randomized trial," in Cochrane Handbook for Systematic Reviews of Interventions Version 6.1, eds J. P. Higgins, J. Thomas, J. Chandler, M. Cumpston, T. Li, M. J. Page, and V. A. Welch (London: Cochrane), 1539-1558.

Higgins, J. P., and Thompson, S. G. (2002). Quantifying heterogeneity in a meta-analysis. Stat. Med. 21, 1539-1558. doi: 10.1002/sim.1186

Klein, C. P., dos Santos Rodrigues, K., Hözer, R. M., de Sá Couto-Pereira, N., Saccomori, A. B., Dal Magro, B. M., et al. (2018). Swimming exercise before and during pregnancy: promising preventive approach to impact offspring's health. Int. J. Dev. Neurosci. 71, 83-93. doi: 10.1016/j.ijdevneu.2018.08.009

Koniak-Griffin, D. (1994). Aerobic exercise, psychological well-being, and physical discomforts during adolescent pregnancy. Res. Nurs. Health 17, 253-263. doi: 10.1002/nur.4770170404

Lederman, S. A., Paxton, A., Heymsfield, S. B., Wang, J., Thornton, J., and Pierson, R. N. Jr. (1997). Body fat and water changes during pregnancy in women with different body weight and weight gain. Obstet. Gynecol. 90(4 Pt 1), 483-488. doi: 10.1016/S0029-7844(97)00355-4

Lee, A. M., Lam, S. K., Sze Mun Lau, S. M., Chong, C. S., Chui, H. W., and Fong, D. Y. (2007). Prevalence, course, and risk factors for antenatal anxiety and depression. Obstet. Gynecol. 110, 1102-1112. doi: 10.1097/01.AOG.0000287065.59491.70

Li, D., Liu, L., and Odouli, R. (2009). Presence of depressive symptoms during early pregnancy and the risk of preterm delivery: a prospective cohort study. Hum. Reprod. 24, 146-153. doi: 10.1093/humrep/den342

Martinsen, E. W. (2008). Physical activity in the prevention and treatment of anxiety and depression. Nord. J. Psychiatry 62(Suppl. 47), 25-29. doi: 10.1080/08039480802315640

Moher, D., Shamseer, L., Clarke, M., Ghersi, D., Liberati, A., Petticrew, M., et al. (2015). Preferred reporting items for systematic review and meta-analysis protocols (PRISMA-P) 2015 statement. Syst. Rev. 4, 1-9. doi: 10.1186/2046-4053-4-1

Mosquera-Valderrama, Y. F., Robledo-Colonia, A. F., and Ramírez-Vélez, R. (2012). Ensayo clínico controlado de la influencia del entrenamiento aeróbico en la tolerancia al ejercicio y los síntomas depresivos en primigestantes colombianas. Prog. Obstet. Ginecol. 55, 385-392. doi: 10.1016/j.pog.2012.03.010

Mottola, M. F., Davenport, M. H., Ruchat, S. M., Davies, G. A., Poitras, V., Gray, C., et al. (2018). 2019 Canadian guideline for physical activity throughout pregnancy. Br. J. Sports Med. 52, 1339-1346. doi: 10.1136/bjsports-2018-100056

Nordhagen, I. H., and Sundgot-Borgen, J. (2002). Physical activity among pregnant women in relation to pregnancy-related complaints and symptoms of depression. J. Nor. Med. Assoc. 122, 470-474.

O'Connor, T. G., Heron, J., Golding, J., Beveridge, M., and Glover, V. (2002). Maternal antenatal anxiety and children's behavioural/emotional problems at 4 years. Report from the avon longitudinal study of parents and children. Br. J. Psychiatry 180, 502-508. doi: 10.1192/bjp.180.6.502

Orr, S. T., James, S. A., Garry, J., and Newton, E. (2006). Exercise participation before and during pregnancy among low-income, urban, Black women: the Baltimore Preterm Birth Study. Ethn. Dis. 16, 909-913.

Page, M. J., Moher, D., Bossuyt, P. M., Boutron, I., Hoffmann, T. C., Mulrow, C. D., et al. (2021). PRISMA 2020 explanation and elaboration: updated guidance and exemplars for reporting systematic reviews. BMJ 372:n160. doi: 10.31222/osf.io/gwdhk

Perales, M., Cordero, Y., Vargas, M., Lucia, A., and Barakat, R. (2015). Exercise and depression in overweight and obese pregnant women: a randomised controlled trial. Arch. Med. Deporte 32, 156-163.

Perales, M., Refoyo, I., Coteron, J., Bacchi, M., and Barakat, R. (2014). Exercise during pregnancy attenuates prenatal depression: a randomized controlled trial. Eval. Health Prof. 38, 59-72. doi: 10.1177/0163278714533566

Perales, M., Santos-Lozano, A., Sanchis-Gomar, F., Luaces, M., Pareja-Galeano, H., Garatachea, N., et al. (2016). Maternal cardiac adaptations to a physical 
exercise program during pregnancy. Med. Sci. Sports Exerc. 48, 896-906. doi: 10.1249/MSS.0000000000000837

Rahman, A., Bunn, J., Lovel, H., and Creed, F. (2007). Association between antenatal depression and low birthweight in a developing country. Acta Psychiatr. Scand. 115, 481-486. doi: 10.1111/j.1600-0447.2006.00950.x

Robledo-Colonia, A. F., Sandoval-Restrepo, N., Mosquera-Valderrama, Y. F., Escobar-Hurtado, C., and Ramírez-Vélez, R. (2012). Aerobic exercise training during pregnancy reduces depressive symptoms in nulliparous women: a randomised trial. J. Physiother. 58, 9-15. doi: 10.1016/S1836-9553(12)70067-X

Satyapriya, M., Nagarathna, R., Padmalatha, V., and Nagendra, H. R. (2013). Effect of integrated yoga on anxiety, depression, and well being in normal pregnancy. Complement. Ther. Clin. Pract. 19, 230-236. doi: 10.1016/j.ctcp.2013.06.003

Shivakumar, G., Brandon, A. R., Snell, P. G., Santiago-Muñoz, P., Johnson, N. L., Trivedi, M. H., et al. (2011). Antenatal depression: a rationale for studying exercise. Depress. Anxiety 28, 234-242. doi: 10.1002/da.20777

Shorey, S., Chee, C. Y. I., Ng, E. D., Chan, Y. H., Tam, W. W. S., and Chong, Y. S. (2018). Prevalence and incidence of postpartum depression among healthy mothers: a systematic review and meta-analysis. J. Psychiatr. Res. 104, 235-248. doi: 10.1016/j.jpsychires.2018.08.001

Teixeira, C., Figueiredo, B., Conde, A., Pacheco, A., and Costa, R. (2009). Anxiety and depression during pregnancy in women and men. J. Affect. Disord. 119, 142-148. doi: 10.1016/j.jad.2009.03.005

Uebelacker, L. A., Battle, C. L., Sutton, K. A., Magee, S. R., and Miller, I. W. (2016). A pilot randomized controlled trial comparing prenatal yoga to perinatal health education for antenatal depression. Arch. Womens Ment. Health 19, 543-547. doi: 10.1007/s00737-015-0571-7
Ussher, M., Lewis, S., Aveyard, P., Manyonda, I., West, R., Lewis, B., et al. (2015). Physical activity for smoking cessation in pregnancy: randomised controlled trial. BMJ 350:h2145. doi: 10.1136/bmj.h2145

Vargas-Terrones, M., Barakat, R., Santacruz, B., Fernandez-Buhigas, I., and Mottola, M. F. (2019). Physical exercise programme during pregnancy decreases perinatal depression risk: a randomised controlled trial. Br. J. Sports Med. 53, 348-353. doi: 10.1136/bjsports-2017098926

Wisner, K. L., Sit, D. K. Y., Hanusa, B. H., Moses-Kolko, E. L., Bogen, D. L., Hunker, D. F., et al. (2009). Major depression and antidepressant treatment: impact on pregnancy and neonatal outcomes. Am. J. Psychiatry 166, 557-566. doi: 10.1176/appi.ajp.2008.08081170

World Health Organization (2004). Invertir en salud mental. Available online at: https://apps.who.int/iris/handle/10665/42897 (accessed December 5, 2020).

Conflict of Interest: The authors declare that the research was conducted in the absence of any commercial or financial relationships that could be construed as a potential conflict of interest.

Copyright (C) 2021 Sánchez-Polán, Franco, Silva-José, Gil-Ares, Pérez-Tejero, Barakat and Refoyo. This is an open-access article distributed under the terms of the Creative Commons Attribution License (CC BY). The use, distribution or reproduction in other forums is permitted, provided the original author(s) and the copyright owner(s) are credited and that the original publication in this journal is cited, in accordance with accepted academic practice. No use, distribution or reproduction is permitted which does not comply with these terms. 